\title{
Efek Senam Lanjut Usia Terhadap Peningkatan Aktifitas Fisik Lanjut Usia Di Dusun Bonorejo Kelurahan Plesungan
}

\author{
Saelan ${ }^{1,}$ Galih Setia Adi $^{2}$ Sahuri Teguh Kurniawan ${ }^{3,}$ Kukuh Ardian $^{4}$ \\ 1,2,3 Prodi Profesi Ners FIK Universitas Kusuma Husada Surakarta \\ ${ }^{4}$ Prodi Adminkes Universitas Kusuma Husada Surakarta, Indonesia \\ 1'saelanelan@ukh.ac.id*,2galihkh88@gmail.com, ${ }^{3}$ s_sahuri@yahoo.com, ${ }^{4}$ kukuh.ardph@gmail.com \\ *corresponding author
}

\begin{tabular}{l}
\hline INFORMASI ARTIKEL \\
\hline Sejarah artikel: \\
Received: $11-04-2020$ \\
Revised: 18-04-2020 \\
Accepted: $23-05-2020$
\end{tabular}

\section{ABSTRAK}

Masalah yang sering muncul pada lansia adalah aktifitas fisik yang kurang sehingga akan mempengaruhi kondisi kebugaran lansia. Senam dapat meningkatkan kemampuan aktifitas dan dapat meningkatkan kebugaran karena pada lansia diperlukan aktifitas ringan untuk melatih kerja jantung yang sudah mengalami penurunan. Tujuan Penelitian ini untuk mengetahui Efek Senam Lansia Terhadap Peningkatan Aktifitas Fisik Lanjut Usia Di Dusun Bonorejo Desa Plesungan Kabupaten Karanganyar. Rancangan penelitian ini adalah jenis eksperimen dengan teknik Pretest and Posttest

\section{Kata kunci:}

senam lansia, kebugaran aktifitas fisik, lansia pada kelompok intervensi dan kelompok kontrol. Variabel independen dalam penelitian ini adalah senam lansia sedangkan variabel dependennya adalah aktifitas fisik. Teknik yang digunakan adalah purposive sampling yaitu pengambilan sampel dengan kriteria yang dikehendaki peneliti yaitu sejumlah 30 responden. Kriteria sampel dalam penelitian ini adalah lansia usia 60 tahun ke atas, tidak memiliki masalah kesehatan fisik. Intervensi yang digunakan untuk mengukur peningkatan aktifitas fisik adalah uji jalan kaki selama 6 menit. Hasil penelitian pada kelompok perlakuan pengukuran pre test sebanyak 14 responden $(46,7 \%)$ memiliki kemampuan berjalan selama 6 menit dan 16 responden tidak mampu berjalan selama 6 menit dan pengukuran post test sebanyak 28 responden $(93,3 \%)$ memiliki kemampuan berjalan selama 6 menit, sedangkan 2 responden $(6,7 \%)$ tidak mampu berjalan selama 6 menit. Analisis bivariat pada kelompok intervensi menggunakan uji wilxocon didapatkan hasil $\mathrm{p}$ value $0,001<0,05$ Ho ditolak Ha diterima artinya ada Efek Senam Lanjut Usia Terhadap Peningkatan Aktifitas Fisik Lanjut Usia.

\section{Key word: Elderly Gymnastics, Physical Activity Health, Elderly.}

\section{ABSTRACT}

The problem that often arises in the elderly is the lack of physical activity that is less affect the elderly health condition. These activities can increase the ability of the activity and can improve fitness because the elderly are needed mild activities to train the work of the heart that has decreased Gymnastics will help the body stay fresh and fit because it keeps the bones strong, encourages the heart to work optimally, and removes free radicals in the body. It is necessary to conduct elderly gymnastics research on the health of elderly Physical Activity at Village of Bonorejo, Plesungan Village. The purpose of this study was to analyze the effect of elderly gymnastics on the health of the elderly physical activity. Experimental research methods with One Group Design Pre-test and Post-test techniques. Purposive sampling was used to determine its samples. It is a technique of determining the sample among the population through the researcher wants. The number of the sample was 30 respondents. The sample criteria were the elderly aged 60 years and over and did not have physical health problems. Measurement of physical activity health applied a walk test for 6 minutes. The pre-test measurement result in the treatment group showed 14 respondents (46.7\%) could walk for 6 minutes and 16 respondents were unable to walk for 6 minutes. The post-test measurement revealed 28 respondents (93.3\%) could walk for 6 minutes and 2 respondents (6.7\%) were unable to walk for 6 minutes. Bivariate test with Wilxocon in the 
intervention group obtained p-value of $0.001<0.05 \mathrm{Ho}$ is rejected $\mathrm{Ha}$ is accepted meaning that there are effects of Elderly Gymnastics Against Increased Physical Activity of Elderly.

\section{PENDAHULUAN}

Keberhasilan pembangunan bidang kesehatan merupakan salah satu bentuk peningkatan kesehatan lanjut usia. Berdasarkan World Population Prospect tahun 2017, Indonesia adalah negara yang terdiri dari beberapa pulau dengan peringkat ke empat di dunia, hal ini mempengaruhi jumlah penduduk dunia. Menurut Mega dkk, 2018 mulai tahun 2017 hingga 2050 diperkirakan separuh dari pertumbuhan penduduk dunia akan terkonsentrasi pada sembilan negara saja diantaranya Indonesia. Populasi lanjut usia yang berusia 60 tahun ke atas sebesar 7\%. Semakin meningkatnya jumlah harapan hidup lansia berpengaruh terhadap pertumbuhan penduduk. Pada tahun 2017 jumlah lansia sekitar 962 juta orang lebih dari dua kali lipat dibandingkan pada tahun 1980 sebesar 382.000 .000 di seluruh dunia. pada tahun 2050, jumlah lansia mencapai dunia sekitar 2,1 miliar di seluruh.

Menua dapat menjadi suatu ketakutan sendiri dalam berbagai hal, salah satunya segi kesehatan (Mujib, 2016). Gangguan fungsional yang berupa disabilitas semakin meningkat dengan bertambahnya usia. Hal ini sesuai dengan disabilitas ringan yang diukur dengan kemampuan melakukan Activity of Daily Living (ADL) diperkirakan sebanyak 51\% lanjut usia. Usia 55-64 tahun, distribusi prevalensi sekitar 51\% dan pada usia 65 ke atas sejumlah 62\%; pada usia 55-64 mengalami disabilitas berat sekitar $7 \%$ tahun, pada usia 65-74 tahun mengalai disabilitas $10 \%$, serta pada usia 75 tahun ke atas sekitar 22 (Ari,2016).

Data proyeksi penduduk pada tahun 2017 didapatkan penduduk usia lanjut di Indonesia sejumlah 9,03\%. Atau 23,66 juta jiwa. Jumlah penduduk lanjut usia tahun 2020 diperkirakan mencapai 27,08 juta, pada tahun 2025 (33,69 juta), dan tahun 2030 (40,95 juta), sedangkan tahun 2035 dapat mencapai 48,19 juta. Kondisi fisik dan psikis dapat menyebabkan ketergantungan pada lansia, bahwa lansia mengalami perkembangan yang mengarah ke perubahan yang negatif.

Berdasarkan data Riset Kesehatan Dasar tahun 2013 penyakit pada lansia diantaranya hipertensi (57,6\%), artritis (51,9\%), Stroke $(46,1 \%)$, masalah gigi dan mulut $(19,1 \%)$, penyakit paru obstruktif menahun (8,6\%) dan diabetes mellitus $(4,8 \%)$. Hal ini bisa dipengaruhi karena perubahan perilaku dan pola hidup lansia.

Undang-undang Nomor 13 Tahun 1998 yang mengatur tentang Kesejahteraan Lanjut Usia, bahwa pelayanan kesehatan harus diberikan sebagai salah satu upaya untuk memenuhi hak lansia dalam meningkatkan kesejahteraan sosialnya. Pelayanan kesehatan lansia dalam rangka memelihara dan meningkatkan derajat kesehatan dan kemampuan penduduk lansia agar kondisi fisik, mental, dan sosial bisa berfungsi sesuai perubahan yang terjadi pada lanjut usia.

Senam lansia merupakan olah raga ringan yang tidak memberatkan lansia sehingga dapat meningkatkan kebugaran tubuh pada lansia. Manfaat lainnya adalah mendorong jantung bekerja optimal dan membantu membuang radikal bebas di dalam tubuh. Senam lansia dapat dilakukan setiap pagi dalam bentuk gerakan jalan santai, joging dan lain-lain. Hasil observasi pada tanggal 12 Februari 2019 di posyandu lansia Dusun Bonorejo didapatkan 17 lansia tidak melakukan aktifitas hanya berdiam diri di rumah, kegiatan posyandu lansia tidak melakukan kegiatan aktifitas ringan pada lansia, kader posyandu mengatakan belum mempunyai program untuk lansia dalam meningkatkan kebugaran lansia, 10 lansia setelah dilakukan uji jalan selama 6 menit lansia mengatakan lemas karena jarang olah raga. Tujuan penelitian ini adalah mengetahui Peningkatan Aktifitas Fisik Lanjut Usia Di Dusun Bonorejo Kelurahan Plesungan.

\section{METODE PENELITIAN}

Penelitian yang digunakan dalam penelitian ini adalah penelitian quasi experiment dengan dilakukan Pre - test and Post - test. Populasi lansia yang mengikuti senam lansia pada kelompok posyandu Lansia di Dusun Bonorejo Desa Plesungan sejumlah 30 orang. Sampel dipilih berdasarkan purposive sampling. 
Sampel yang terpilih, yakni lanjut usia yang memenuhi kriteria inklusi sebagai berikut : Lanjut usia yang berumur $>60$ 90 tahun, Lansia yang sadar penuh dan dapat mengikuti senam dan berinteraksi, Tidak sedang mengikuti aktivitas/ latihan ROM lainnya, Tidak menggunakan alat bantu jalan. Menurut Nury et al, 2011 untuk mengukur kemampuan aktifitas

\begin{tabular}{lcc}
\hline \multicolumn{1}{c}{ Karakteristik } & $\mathrm{F}$ & $\%$ \\
\hline $\begin{array}{l}\text { Mampu bejalan } \\
6 \text { menit }\end{array}$ & 14 & 46,7 \\
$\begin{array}{l}\text { Tidak Mampu } \\
\text { bejalan 6 menit }\end{array}$ & 16 & 53,3 \\
\hline \multicolumn{1}{c}{ Total } & 30 & 100
\end{tabular}

fisik Instrumen yang digunakan yaitu American Thoracic Society (2012) enam menit berjalan kaki merupakan alat penelitian untuk menguji toleransi latihan pada penyakit pernafasan kronis dan gagal jantung.

\begin{tabular}{ccc}
\hline Karakteristik & f & $\%$ \\
\hline $\begin{array}{c}\text { Rata- rata usia } \\
\text { lansia }\end{array}$ & 65,83 & 6,18 \\
\hline Laki- laki & 12 & 40 \\
Perempuan & 18 & 60 \\
\hline Pekerjaan & 19 & 64 \\
Pensiun & 6 & 20 \\
tidak bekerja & 4 & 13 \\
Wiraswasta & 1 & 3 \\
Pedagang & 1 \\
Petani & & \\
\hline
\end{tabular}

HASIL

Hasil data karakteriktik responden di Dusun Bonorejo Desa Plesungan Kabupaten Karanganyar sebagai berikut:

Tabel 1 Karakteristik Responden kelompok perlakuan berdasarkan Umur di Posyandu Cempaka RW 2 RT 02 desa Plesungan $(\mathrm{n}=30)$

Berdasarkan usia rata- rata usia lansia adalah 65 tahun, jenis kelamin antara laki-laki dengan perempuan sejumlah 12 lansia (50,0\%) responden lakilaki dan 18 orang (60\%) responden perempuan, jenis pekerjaan tidak bekerja sebesar 64\%, wiraswasta sebesesar $20 \%$, pedagang sebesar 13\%, dan petani sebesar $1 \%$.
Skor nilai kemampuan berjalan selama 6 menit menunjukkan bahwa pada kelompok perlakuan pengukuran pre test sebanyak 14 responden $(46,7 \%)$ memiliki kemampuan berjalan selama 6 menit dan 16 responden tidak mampu berjalan selama 6 menit.

Tabel 3 Skor nilai kebugaran aktifitas fisik setelah diberikan senam lansia di posyandu lansia desa Plesungan $(n=30)$

\begin{tabular}{ccc}
\hline kemampuan Aktifitas & $\mathrm{F}$ & $\%$ \\
\hline $\begin{array}{c}\text { Mampu berjalan } 6 \\
\text { menit }\end{array}$ & 28 & 93,3 \\
$\begin{array}{c}\text { Tidak Mampu berjalan } 6 \\
\text { menit }\end{array}$ & 2 & 6,7 \\
\hline Total & 30 & 100 \\
\hline
\end{tabular}
selama 6 menit menunjukkan bahwa pada kelompok perlakuan pengukuran post test sebanyak 28 responden $(93,3 \%)$ memiliki kemampuan berjalan selama 6 menit dan 2 responden $(6,7 \%)$ tidak mampu berjalan selama 6 menit. Pengaruh senam lansia terhadap kebugaran aktifitas fisik lansia Metode analisa yang digunakan untuk menguji pada kelompok perlakuan menggunakan uji Wilxocon dengan hasil sebagai berikut :

Efek senam lansia terhadap kemampuan aktifitas fisik pada lansia $(\mathrm{n}=30)$

\begin{tabular}{lll}
\hline Data Penelitian & $Z$ & $P$-Value \\
\hline $\begin{array}{l}\text { Skor nilai } \\
\text { kebugaran } \\
\text { aktifitas fisik } \\
\text { sebelum } \\
\text { diberikan senam } \\
\text { lansia }\end{array}$ & & \\
$\begin{array}{l}\text { Skor nilai } \\
\text { kebugaran } \\
\text { aktifitas fisik } \\
\text { setelah diberikan } \\
\text { senamlansia }\end{array}$ & & \\
\hline \multicolumn{1}{c}{ Pada intervensi hasil uji wilxocon }
\end{tabular}
diperoleh pvalue $0,001<0,05$, jadi hasilnya ada pengaruh pemberian senam lansia terhadap kemampuan aktifitas fisik meningkat.

\section{PEMBAHASAN}

Hasil uji kemampuan berjalan selama 6 menit menunjukkan bahwa pada kelompok perlakuan pengukuran pre test 
sebanyak 14 responden $(46,7 \%)$ memiliki kemampuan berjalan selama 6 menit sedangkan pada pengukuran post test sebanyak 28 responden $(93,3 \%)$ memiliki kemampuan berjalan selama 6 menit. Hal ini menunjukkan adanya peningkatan kemampuan berjakan 6 menit sebelum dan sesudah dilakukan senam lansia yaitu sebesar 46,6\%.

Hasil analisis uji wilxocon didapatkan data pada perlakuan diperoleh data pvalue 0,001<0,05 yang artinya terdapat efek senam lansia terhadap kemampuan aktifitas fisik pada lansia. Sesuai penelitian yang dilakukan oleh Ardiyanti (2009) dari hasil penelitian senam lansia dalam kategori sangat baik sebesar 90,57\%. Berdasarkan teori Brick (2001), olahraga aerobik dapat meningkatkan kesehatan fisik lansia, meliputi kesehatan jantung, kesehatan otot, daya tahan otot, kelenturan dan komposisi tubuh.

Hal ini sependapat dengan penelitian Nugroho, 2008 senam aerobik low impact untuk lansia dengan intensitas gerakan ringan sampai sedang, gerakan menyeluruh yang melibatkan gerakan gerakan otot tubuh. Manfaat gerakan aerobik low impact sebagai upaya promotif, preventif, kuratif, dan rehabilitatif pada kesehatan lansia.

Senam lansia merupakan upaya peningkatan kebugaran aktifitas fisik jasmani yang baik. Kebugaran aktifitas fisik meliputi kekuatan otot, kelenturan persendian, kelincahan gerak, keluwesan, kardiovaskuler fitness dan neuro muskular fitnes.

Senam lansia yang dilakukan secara teratur mempunyai dampak positif terhadap peningkatan fungsi organ tubuh, yaitu meningkatnya sistem imunitas. Hasil penelitian ini selain meningkatkan kebugaran aktifitas fisik lansia, selain itu dapat membuat lansia akan merasa lebih berbahagia karena merasa senang berkumpul bersama - sama melakukan senam lansia, senantiasa merasa gembira, bisa tidur lebih nyenyak, dan pikiran lebih tenang sehingga akan meningkatkan kesehatan pada lansia.

Menurut Darmojo, 2009 senam lansia yang dilakukan secara teratur dapat mencegah terjadinya penurunan dan kekuatan masa otot. Sehingga akan berpengaruh terhadap kestabilan denyut jantung.
Penelitian lain yang dilakukan oleh Wahyuni (2015) menyimpulkan bahwa senam lansia dapat melancarkan pembuluh darah kapiler, kemudian terjadi vasodilatasi (pelebaran) pada pembuluh darah yang mengakibatkan transportasi oksigen ke seluruh tubuh menjadi lancar. Aktivitas olahraga yang teratur dapat membakar glukosa dalam tubuh melalui aktivitas otot yang menghasilkan energi ATP akan berpengaruh pada endophrin sehingga memberi rasa nyaman, senang, dan bahagia. Aktifitas olah raga ini akan merangsang mekanisme HPA (Hypothalamus Pituitary Adrenal) axis yang akan diteruskan ke kelenjar pituitary (hipofisis) akan menghasilkan beta endorphin sehingga memberikan perasaan tenang dan rileks. Lansia dapat melakuka aktifitas tersebut secara mandiri.

Menurut penelitian Yurintika (2015) menyatakan bahwa Senam lansia dapat meningkatkan peredaran oksigen ke seluruh tubuh khususnya ke otak menjadi lancar. Terpenuhinya oksigen akan meningkatkan relaksasi otot, yang mengoptimalkan sekresi melatonin, beta endorphin dan membantu peningkatan pemenuhan aktivitas fisik lanjut usia. Hal ini sesuai dengan penelitian yang dilakukan oleh Adiyana (2013), di mana senam dapat menstimulasi kontraksi pembuluh darah kapiler yang akan merubah melebarnya pembuluh darah yang disebut dengan vasodilatasi kapiler. Aliran oksigen dalam darah semakin lancar sehingga memacu hormon endorphin dan memacu lansia untuk dapat beraktivitas dengan baik. Kegiatan aktifitas ini sangat penting khususnya pada lansia karena mengalami aging proses.

\section{KESIMPULAN DAN SARAN} KESIMPULAN

1. Rata- rata responden berusia 65 tahun, responden jenis kelamin lakilaki sebanyak 40,0\% sedangkan responden perempuan sebanyak 60\%.

2. Kemampuan berjalan selama 6 menit menunjukkan bahwa pada kelompok perlakuan pengukuran pre test sebanyak 14 responden $(46,7 \%)$ memiliki kemampuan berjalan selama 6 menit dan 16 responden tidak mampu berjalan selama 6 menit 
3. Kemampuan berjalan selama 6 menit menunjukkan bahwa pada kelompok perlakuan pengukuran post test sebanyak 28 responden (93,3\%) memiliki kemampuan berjalan selama 6 menit dan 2 responden $(6,7 \%)$ tidak mampu berjalan selama 6 menit

4. Terdapat pengaruh pemberian Senam Lanjut Usia Terhadap Peningkatan Aktifitas Fisik Lanjut Usia Di Dusun Bonorejo Kelurahan Plesungan.

\section{SARAN}

1. Bagi Peneliti:

Penelitian ini dapat dijadikan sebagai refernsi dalam menentukan upaya preventif dan promotif di posyandu lansia.

2. Bagi Posyandu:

Penelitian ini dapat dijadikan intervensi pada lansia untuk kegiatan pengabdian kepada masyarakat.

3. Rencana selanjutnya

Tahap kegiatan berikutknya adalah hasil penelitian ini akan digunakan untuk pelaksanaan kegiatan pengabdian kepada masyarakat.

\section{DAFTAR PUSTAKA}

Akmal, S.A (2012). Diagnosis Dan Penatalaksanaan Insomnia Pada Lanjut Usia. Diakses pada tanggal 19 mei 2017 jam 09:00. http://infopenyakitdalam.com

Anggraini, F. (2008). Hubungan antara gaya hidup dan status kesehatan lansia binaan puskesmas pekayon jaya kota Bekasi.(Skripsi).Bekasi: Universitas Indonesia

Anggriyana, T. (2010). Senam kesehatan Aplikasi Senam untuk Kesehatan.Yogyakarta: Nuha Medika

Ari W, et all, 2016. Pengaruh Senam Lansia Terhadap Peningkatan Kebugaran aktifitas fisik Fisik Pada Kelompok Lansia Perempuan Di Desa Dauh Puri Kauh Denpasar Barat, Universitas Udaya : Denpasar Bali

Arikunto, Suharsimi. (2010). Prosedur Penelitian Suatu Pendekatan Praktik.Jakarta:Rineka Cipta

Kementerian Kesehatan RI.(2013a). Gambaran Kesehatan Lanjut Usia di Indonesia.Jakarta:Kementerian Kesehatan RI
Asmadi. (2009). Konsep Dasar Keperawatan.Jakarta:EGC

Azizah, lilik M. (2011). Keperawatan Lanjut Usia.Yogyakarta:Graha Ilmu

Bandiyah. (2009). Lanjut Usia dan Keperawatan Gerontik.Yogyakarta:Nuha.Medika

Burns \& Susan. (2008). The Practice of Nursing Research Conduct,Critique and Utilization.USA: Elsevier

Buysse,D.J., Reynolds III,C.F., Monk, T.H., Berman, S.R., \& Kupfer, D.J.(1989) The Pittsburgh Sleep Quality Index: A New Instrument for Psychiatric Practice and Research. Journal of Psychiatric Research, 28 (2), 193-213

Cahyono, K. H. (2012). Pengaruh Senam Lansia Terhadap Kualitas Tidur pada Lansia di Desa Leyangan Kecamatan Ungaran Timur Kabupaten Semarang. Ungaran: STIKES Ngudi Waluyo

Chandra, Budiman.(2008). Metodologi Penelitian Kesehatan.Jakarta:EGC

Chennaoui, M., Arnal, P. J., Sauvet, F., \& Leger, D. (2014). Sleep Medicine Reviews.

Doi:

10.1016/j.smrv.2014.06.008

Darmojo, Boedhi.(2015). Geriatri Ilmu Kesehatan Usia Lanjut.Jakarta:Balai Penerbit FK- UI.Jakarta:EGC

Depkes RI. (2009). Sistem Kesehatan Nasional.Jakarta

Dianingtyas, A \& Sarah,U. (2008). Perbedaan Tingkat Depresi Pada Lansia Sesudah dan Sebelum dilakukan Senam Bugar Lansia di PSTW Wening Wardoyo Ungaran. Jurnal Kesehatan Vol.2 No.1

Elliot, D., 2010, Patofisiologi Aplikasi pada Praktek Keperawatan, 112113.Jakarta:EGC

Guyton \& Hall.(2008). Buku Ajar Fisiologi Kedokteran:EGC

Hidayat Alimul Aziz. (2008). Riset Keperawatan dan Teknik Penulisan Ilmiah. Edisi 2. Cetakan ketiga. Jakarta: Salemba Medika

Kasjono, Heru Subaris dan Yasril. Teknik Sampling Untuk Penelitian Kesehatan, 1th ed. Yogyakarta:Graha Ilmu Khasanah K dan Hidayati W. 2012. Kualitas Tidur Lansia Balai Rehabilitasi Sosial "MANDIRI" Semarang. Jurnal Nursing Studies, $1(1)$ : 189-196. 
Kozier, Barbara.(2008). Fundamental Of Nursing: Concepts, Process, and Practice New Jersey: Berman Audrey

Maas, L. Meridean.(2011). Asuhan Keperawatan Geriatrik:Diagnosis Kriteria Hasil NOC \&intervensi NIC. Jakarta:EGC

Maryam, et al.(2012). Mengenal Usia Lanjut \& Perawatannya. Jakarta:Salemba Medika

McCann D., Stewart J. (2008). Musical Learning.http://www.tms.com.au/tm s12-1m.html, 16 Mei 2008

Mega dkk, (2018), Pusat statistik Penduduk Lanjut Usia: Badan Pusat Statistik.

Mujib, M., \& Suprayitno, E. (2016). PENGARUH LATIHAN RANGE OF MOTION (ROM) TERHADAP PERUBAHAN SKALA NYERI PADA LANSIA DENGAN OSTEOARTRITIS DI POSYANDU LANSIA DESA KALIANGET TIMUR KECAMATAN KALIANGET KABUPATEN SUMENEP. Journal Of Health Science (Jurnal Ilmu Kesehatan), 1(2), 55-62.

Notoatmojo, soekidjo.(2010). Metodologi Penelitian Kesehatan. Jakarta:Rineka Cipta

Novitaningtyas, T. (2014). Hubungan Karakteristik (Umur, Jenis Kelamin, Tingkat Pendidikan) dan Aktivitas Fisik dengan Tekanan Darah pada Lansia di Kelurahan Makam Haji Kecamatan Kartasura Kabupaten Sukoharjo. Skripsi. Surakarta: UMS.

Nugroho, Wahyudi.(2008). Keperawatan Gerontik dan Geriatrik. Jakarta: Fakultas Kedokteran ECG Edisi 3

Nursalam.(2008). Konsep \& Penerapan Metodologi Penelitian Ilmu Keperawatan: Pedooman Skripsi, Tesis, \& Instrumen. Edisi 2.Jakarta: Salemba Medika

Padila. (2012). Buku Ajar Keperawatan Keluarga.Yogyakarta: Nuha Medika

Panti Sosial Tresna Whreda Warga Tama, Pengambilan Data Awal Usia Lanjut, Indralaya, 2012

Potter, P.A \& Perry A.G. (2011). Fundamental of Nursing. Jakarta:EGC

Prasadja, A. (2009). Ayo Bangun Dengan Bugar Karena Tidur yang Benar.Jakarta: Penerbit Hikmah
Putra,sitiatava rizema.(2011). Tips Sehat Dengan Pola Tidur Tepat dan Cerdas. Yogyakarta: Buku Biru

Rachmat, C. (2015). "Pengaruh Senam Poco-Poco Terhadap Kadar Trigliserida Darah". Universitas Sam Ratulangi: Manado

Rahman, 2013 Hubungan Antara Kolesterol Total Darah dengan Vo2maks Melalui Uji Jalan 6 Menit. Sain medika, Vol (1).

Santoso.(2010). Statistik Multivariat Konsep \& Aplikasi dengan SPSS. Jakarta: Elex Medika Komputindo

Saputra. A, D. (2015). "Pengaruh Senam Poco-Poco Terhadap Kadar Kolesterol Low Density Lipoprotein Darah". Universitas Sam Ratulangi: Manado

Sastroasmoro \& Ismael.(2008). DasarDasar Metodologi Penelitian Klinis. Edisi Ketiga. Jakarta:Sagung Seto

Siti Aisyah, 2013. Pengaruh Senam Lansia Terhadap aktifitas Sehari- Hari pada Lansia di Desa Wijen Ungaran Kelurahan Gedangan Kecamatan Ungaran barat: prodi Ilmu Keperawatan Stikes Ngudi waluyo.

Stenley, M and Beare, PG.(2009). Buku Ajar Keperawatan Gerontik. Edisi 2. Jakarta:EGC

Stockslager, Jamie L.(2008). Asuhan Keperawatan Geriatrik, Edisi 2. Jakarta:EGC

Subagyo, Pangestu dan Djarwanto.(2009).Statistik Induktif, 5th ed. Yogyakarta: BPFE

Sumedi, T. (2010). "Pengaruh Senam Lansia Terhadap Penurunan Skala Insomnia Pada Lansia Di Panti Wredha Dewanata Cilacap". Poltekkes Depkes: Purwokerto

Sunaryo . (2016).Asuhan Keperawatan Gerontik. Yogyakarta: Andi

Susenas, (2015) Penduduk Lanjut Usia dan Keterjangkauan Program Perlindungan Sosial Bagi Lansia.

Tamher S, Noorkasiani. Kesehatan Usia Lanjut Dengan pendekatan Asuhan Keperawatan Salemba Mediak Jakarta, 2009.

Widianti, AT dan Proverati, A.2010. Senam Kesehatan: Yogyakarta. Naha Med 